\title{
STUDY OF ENTEROPARASITES INFECTION FREQUENCY AND CHEMOTHERAPEUTIC AGENTS USED IN PEDIATRIC PATIENTS IN A COMMUNITY LIVING IN PORTO ALEGRE, RS, BRAZIL
}

\author{
Fernanda B. MORRONE, Juliana A. CARNEIRO, Cristine dos REIS, Cibele M. CARDOZO, Caroline UBAL \& Geraldo A. DE CARLI
}

\begin{abstract}
SUMMARY
Parasitic infections caused by intestinal protozoan and helminths affect more than two billion people worldwide and chemotherapy is the most commonly used therapeutic procedure. Considering the problems created by parasitic infections and the incorrect use of drugs, the aim of this work was to detect the frequency of enteroparasites infection and to estimate the use of chemotherapeutic agents in children living in the periphery of the city of Porto Alegre, RS, Brazil. Ninety-six preschool age children, who had parasitological exams and who used antiparasitic drugs, were analyzed. The efficacy of treatment was evaluated by stool examination repeated six months after treatment. The same diagnostic test was used to evaluate parasitological cure, which was defined as absence of eggs and cysts in the stool. From these children, $79(82.3 \%)$ were contaminated by some species of parasite, the most prevalent were Ascaris lumbricoides, Trichuris trichiura and Giardia lamblia. The most commonly used drugs were mebendazole (86\% of prescriptions) and metronidazole (30.3\%). The cure rate in the 79 children, examined 6 months after treatment, was $65.3 \%$ for A. lumbricoides and $66.1 \%$ for $T$. trichiura. This study suggests that a continuous education program regarding the prevention and treatment of parasitic infections is an essential tool for their eradication.
\end{abstract}

KEYWORDS: Chemotherapeutic agents; Drug utilization study; Pharmaceutical care; Parasitic infections.

\section{INTRODUCTION}

Parasitic infections, caused by intestinal protozoan and helminths, affect more than two billion people worldwide ${ }^{28}$. These infections are more prevalent in the poorest sections of the population and re-infection in endemic areas is continuous ${ }^{5,6}$. According to the WHO, 980 million people are infected with intestinal roundworm Ascaris lumbricoides ${ }^{28}$. Several studies show that the prevalence of A. lumbricoides and Trichuris trichiura is very high in the patients examined, when compared with other parasites such as Giardia lamblia, Strongyloides stercoralis, Hymenolepis nana and others ${ }^{4,8,9,10,17,21,22,27}$.

Among the conditions influencing the development of these infections are poor sanitary conditions, lowering resistance of the host, population explosion, inadequate control of vectors and infection of reservoirs, increased migration, military operation and travelling around the world ${ }^{15,20,24}$. This disease can undermine child development, educational achievement, reproductive health and social and economic development ${ }^{1,3}$ and some parasitic infections can cause morbidity and mortality ${ }^{14}$. Nevertheless, treatment is often neglected for economic reasons and because most patients have no symptoms ${ }^{1}$.

Chemotherapy is the cornerstone of the strategy of control of morbidity, reduction of transmission and delay of soil-transmitted helminth re-infection ${ }^{3,11}$. The benzimidazole antihelminthics are largely used for treating intestinal nematode infection together with praziquantel for schistosomiasis ${ }^{7,16,19}$. These drugs are safe, inexpensive and very effective, have a broad-spectrum of activity, and easy administration ${ }^{3,15}$. Anthelminthic resistance may develop more slowly than in other agents, although, a recent study indicates that benzimidazole resistance has developed in hookworms after treatment of infected patients ${ }^{11}$.

Chemotherapy is the most used therapeutic procedure, however, many treatments do not obtain their goal due to the incorrect use of drugs ${ }^{25}$. Tests on the efficacy of chemotherapeutic agents can be used, these include cure rate, egg-reduction rate and the occurrence of any side effects due to administration of the drugs.

Therefore, actions by the health professional are necessary to provide adequate clinical care within the health system $^{28}$. Pharmacists, in the modern health system, also have a responsibility to provide patient education regarding treatment as well as diagnostic investigation ${ }^{12}$. According to OLSEN et al., health education is an important factor in the prevention of parasitic infections ${ }^{20}$.

Considering the problems created by parasitic infections and the 


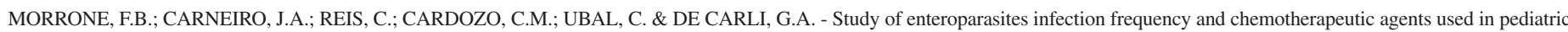
patients in a community living in Porto Alegre, RS, Brazil. Rev. Inst. Med. trop. S. Paulo, 46(2):77-80, 2004

incorrect use of drugs, the aim of this work was to detect the frequency of enteroparasites infection and to estimate the use of chemotherapeutic drugs in children living in the periphery of Porto Alegre, RS, Brazil.

\section{MATERIALS AND METHODS}

Population: Prospective data collection was performed during the year 2002-2003. Ninety-six children of pre-school age and of both sexes were analyzed, children were chosen randomly from the patients of a Public Health Center, Porto Alegre, RS, Brazil.

Diagnostic test: The fecal specimens were collected and screened for a complete ova and parasite examination $(\mathrm{O} \& \mathrm{P})$ by the gravity sedimentation technique ${ }^{13,16}$ and the Baermann method ${ }^{2}$. One sample from each patient was examined within a period of $12 \mathrm{~h}$ after the collection and parents signed an informed consent form. Immediately after the stool examination, treatment was given to the children with positive stool findings. The efficacy of treatment was evaluated by stool examination repeated six months after treatment. The same diagnostic test was used to evaluate parasitological cure, which was defined as absence of eggs and cysts in the stool.

Pharmaceutical care program: After the prescription of medication, an interview was performed with the patients and their parents. The questionnaire contained information on the patient's age, habits, prescribed drugs, and treatment regimen. The Pharmaceutical Care Program provided the patients and parents with information about basic health hygiene notions, drug prescriptions and the correct use of drugs. This study was approved by the Institutional Ethics Committee.

Data analysis: The data were collected and the results were kept in individual patient files together with the diagnostic tests, the questionnaires and interventions realized. The computer program, Epiinfo, was used to analyze the data and cure rate was presented as the percentage of the data set.

\section{RESULTS}

In this survey, 96 children of pre-school age were investigated. Table 1 shows the characteristics of children infected, where the mean age of the female infected was $4.43( \pm 2.36)$ and the non-infected was 3.14 $( \pm 1.77)$. The mean age of the infected male children was $4.45( \pm 2.65)$ and the non-infected was $2.62( \pm 3.06)$. The total number of infected children before treatment was $79(82.3 \%)$ and $17(17.7 \%)$ non-infected. Of these, $46(47.9 \%)$ were female infected children and 7 (7.3\%) noninfected. The total number of male children infected was $33(34.4 \%)$ and non-infected males was 10 (10.4\%) (Table1).

According to the results, $79(82.3 \%)$ children were contaminated by some parasite. Table 2 shows the distribution of the specific enteroparasites, the most prevalent parasites were A. lumbricoides (49; $62 \%)$, T. trichiura $(46 ; 58.2 \%)$ and G. lamblia $(16 ; 20.3 \%)$ (Table 2). The children were infected with Hymenolepis nana, Strongyloides stercoralis and other protozoa.

Table 3 depicts the chemotherapeutic agents most commonly used in the infected patients. Of the 79 infected patients that received treatment with one or more chemotherapeutic agent, $68(86.1 \%)$ received
Table 1

Sex and age composition prevalence, and intensity of parasites among preschool age children in an urban slum, Porto Alegre, RS $(n=96)$

\begin{tabular}{lcc}
\hline Sex & Negative cases & Positive cases \\
\hline Children's age F/M & $3.14 \pm 1.77 /$ & $4.43 \pm 2.36 /$ \\
& $2.62 \pm 3.06^{\mathrm{b}}$ & $4.45 \pm 2.65$ \\
Female & $7(7.3 \%)$ & $46(47.9 \%)$ \\
Male & $10(10.4 \%)$ & $33(34.4 \%)$ \\
Total & $17(17.7 \%)$ & $79(82.3 \%)$ \\
\hline
\end{tabular}

${ }^{\mathrm{a}} \mathrm{F}=$ female $; \mathrm{M}=$ male; ${ }^{\mathrm{b}}$ Mean $\pm \mathrm{SD}$

Table 2

Parasites distribution in pre-school age children $(\mathrm{n}=79)$

\begin{tabular}{lcc}
\hline Parasites & Frequency* & Percentage (\%) \\
\hline Helminths & 49 & $62.0 \%$ \\
Ascaris lumbricoides & 46 & $58.2 \%$ \\
Trichuris trichiura & 3 & $3.8 \%$ \\
Strongyloides stercoralis & 5 & $6.3 \%$ \\
Hymenolepis nana & & \\
Protozoan & 1 & $1.3 \%$ \\
Entamoeba spp.** & 8 & $10.1 \%$ \\
Entamoeba coli & 6 & $7.6 \%$ \\
Endolimax nana & 16 & $20.3 \%$ \\
Giardia lamblia &
\end{tabular}

*Some specimens had more than one parasite. **Entamoeba histolytica is being used to designate pathogenic zymodemes, while E. dispar is now being used to designate nonpathogenic zymodemes. However, unless trophozoites containing ingested red blood cells (E. histolytica) are seen, the two organisms cannot be differentiated on the basis of morphology.

anthelminthic mebendazole, $24(30.4 \%)$ patients received metronidazole, $5(6.3 \%)$ patients received praziquantel and $3(3.8 \%)$ patients received anthelminthic tiabendazole. The most used drug was mebendazole with a treatment regimen of $600 \mathrm{mg}$ multiple-dose (2 X $100 \mathrm{mg}$ over three days). Other drug regimens used were $5 \mathrm{mg} / \mathrm{kg}$ three times a day during five to seven days for metronidazole to treat Giardia lamblia, and $10 \mathrm{mg} / \mathrm{kg}$ three times a day for five to seven days to treat Entamoeba. Praziquantel was used at $50 \mathrm{mg} / \mathrm{kg}$ once a day for Hymenolepis nana. To treat Strongyloides stercoralis, tiabendazole $(25 \mathrm{mg} / \mathrm{kg})$ was administered twice daily for two days (Table 3).

Table 3

Various regimens of chemotherapeutic agents in the treatment of parasitic infections $(\mathrm{n}=79)$

\begin{tabular}{lcc}
\hline Regimen of chemotherapeutic agents & $\begin{array}{c}\text { Number of } \\
\text { prescription* }\end{array}$ & Percentage (\%) \\
\hline $600 \mathrm{mg}$ mebendazole multiple dose & 68 & $86.1 \%$ \\
$5 \mathrm{mg} / \mathrm{kg}$ metronidazole multiple dose & 24 & $30.4 \%$ \\
$50 \mathrm{mg} / \mathrm{kg}$ praziquantel single dose & 5 & $6.3 \%$ \\
$25 \mathrm{mg} / \mathrm{kg}$ tiabendazole multiple dose & 3 & $3.8 \%$
\end{tabular}

*Some prescriptions had more than one chemotherapeutic agent prescribed. 
There was an increase in the children's weight after the use of pharmacotherapy where $21(12.9 \%)$ patients demonstrated an increased weight after treatment (data not shown).

Among the children studied the percentage cure rate at examination 6 months after treatment was $65.3 \%$ for A. lumbricoides, $66.1 \%$ for $T$. trichiura and $71.5 \%$ for G. lamblia (Table 4).

\section{Table 4}

Comparison between the intensity of Ascaris lumbricoides, Trichuris trichiura and Giardia lamblia infection in the pre- and post-treatment period in an urban slum, Porto Alegre, RS $(\mathrm{n}=79)$

\begin{tabular}{lccc}
\hline & \multicolumn{2}{c}{ Parasitic prevalence (\%) } & \\
Type of infection & Pre-treatment & Post-treatment & CR (\%) \\
\hline A. lumbricoides & $62.0 \%$ & $34.7 \%$ & $65.3 \%$ \\
T. trichiura & $58.2 \%$ & $33.9 \%$ & $66.1 \%$ \\
G. lamblia & $20.3 \%$ & $18.5 \%$ & $71.5 \%$ \\
\hline
\end{tabular}

$\mathrm{CR}=$ cure rate; defined as absence of eggs in the stool after treatment.

\section{DISCUSSION}

According to our data, most of the children studied were found to be infected by some species of worm. This study was performed in the periphery of Porto Alegre, where families live in inadequate sanitary conditions, reservoirs and vectors are infected, and food and water are contaminated. Many children are more exposed to infections because they have poor hygienic habits and the houses are located near rubbish deposits. The majority of the children's parents, who have a low income, are analphabets, leading us to believe that the heavy intensity of worm infection is related to the low socioeconomic level of the population analyzed.

The high rate of use of mebendazole is justified by the high prevalence of the two intestinal parasites, A. lumbricoides and T. trichiura, in the children studied. It is important to mention that the Public Health Center did not have the antihelminthic, albendazole, available and the medications prescribed were given freely, which limited the choice of prescription.

The pharmacological regimen used in the Public Health Center followed a pattern largely used nowadays. All drug administrations were by oral route, with recommended dosage and frequency of administration according to the prescription. The children also received mineral oil, vitamins and ferrous sulphate to avoid iron-deficiency-related anemia. Each medication prescribed had its own drug regimen, with time of administration and variable doses. This created some difficulties for the parents in understanding how to administrate the drugs prescribed, resulting some times in the non-compliance of treatment. Several studies show that drug regimens with one single oral dose can be as effective and safe as the conventional regimens ${ }^{18,19,23}$. Various combinations of drugs are also suggested for the treatment of parasitic infections in some situations ${ }^{26}$. The current chemotherapeutic agents can be used in novel ways, whilst empiric regimens need continuous clinic evaluation, thus, improved investigations of the use of drugs with different mechanisms against the same parasite or broad-spectrum are needed.
Regarding medication-related problems, we found that some patients did not receive the therapy, or did not adhere to the indicated drug regimen because of lack of information. These problems are very common in people living in poor hygiene and health conditions, with little food, without education and knowledge of the importance of following treatment. Many children examined had already received pharmacological treatment at least six months before. The re-incidence of infection is common twice or three times a year and, therefore, the benefits of a continuous program for high-risk groups as well should be considered.

Nutritional status is an important factor for the adequate absorption and action of the drugs ${ }^{24}$. The majority of patients studied were undernourished, facilitating the process of adverse drug reactions. Thus, a strategy to avoid those side effects in this high-risk group would be the correct use of pharmacotherapy together with an appropriate diet. After the treatment there was a significant increase in the weight of some of the children (data not shown), which led us to believe that the drug therapy was correctly used.

The high cure rate percentage found in our study confirmed the high efficacy of the benzimidazole antihelminthic for A. lumbricoides and $T$. trichiura infections. For the other parasites, geographical variations, genetic differences in the parasites and the quality of drugs (for example lowquality generics) used should be taken into account to explain low cure rates $^{3}$. In addition, we should look at the development of drug resistance, which would cause a decrease in the parasites cure rate as well ${ }^{11}$.

This study suggests that additional support and a continuing health education program, regarding prevention and treatment, is an essential tool for the eradication of the parasitic infections.

\section{RESUMO}

\section{Estudo da freqüência de infecções por enteroparasitos e agentes quimioterápicos usados em pacientes pediátricos em uma comunidade de Porto Alegre, RS, Brasil}

As parasitoses provocadas por protozoários ou helmintos patogênicos afetam mais de dois bilhões de pessoas no mundo. Considerando os problemas gerados por infecções parasitárias e a necessidade do uso correto dos medicamentos prescritos, o objetivo deste trabalho foi detectar a freqüência de infecção por enteroparasitos e o uso de agentes quimioterápicos em crianças moradoras na periferia de Porto Alegre, RS, Brasil. Foram analisadas noventa e seis crianças em idade pré-escolar, que realizaram o exame parasitológico de fezes e que fizeram uso de antiparasitários. A eficácia do tratamento foi avaliada pelo exame parasitológico repetido seis meses após o tratamento. O mesmo teste diagnóstico foi utilizado para avaliar a cura que foi definida como a ausência de ovos e cistos nas fezes. Das crianças estudadas, 79 (82,3\%) estavam infectadas com um ou mais parasitas, os mais prevalentes foram Ascaris lumbricoides, Trichuris trichiura e Giardia lamblia. Os antiparasitários mais utilizados foram mebendazol (86\% das prescrições) e metronidazol $(30,3 \%)$ de acordo com a prevalência da infecção. A porcentagem de cura das 79 crianças estudadas após 6 meses do tratamento foi $65,3 \%$ para A. lumbricoides e $66,1 \%$ para $T$. trichiura. Este estudo sugere que um programa de educação continuada voltado para a prevenção e tratamento das infecções parasitárias tem se mostrado uma ferramenta útil na erradicação destas patologias. 


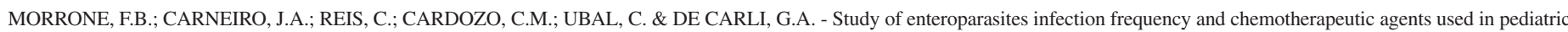
patients in a community living in Porto Alegre, RS, Brazil. Rev. Inst. Med. trop. S. Paulo, 46(2):77-80, 2004.

\section{ACKNOWLEDGEMENTS}

We thank Adriana Tergolina and Dr. Lisiane M. Perez for their collaboration in this study and dedication in promoting public health.

\section{REFERENCES}

1. ALLEN, H.E.; CROMPTON, D.W.T.; SILVA, N.; LOVERDE, P.T. \& OLDS, G.R. New policies for using antihelmintics in high risk groups. Trends Parasit., 18: 381 $382,2002$.

2. BAERMANN, G. - Eine einfache methode zur auffindung von Ankylostomum (Nematoden) larven endproben. Geneesk. Tijd. Nederl. Indie, 57: 131-137, 1917.

3. BENNETT, A. \& GUYATT, H. - Reducing intestinal nematode infection: efficacy of albendazole and mebendazole. Parasit. today, 16: 71-74, 2000.

4. CHIEFFI, P.P.; WALDMAN, E.A.; DIAS, R.M.D.S. et al - Enteroparasitoses no Município de Guarulhos, SP, Brasil. 1. Prevalência de infecção entre escolares residentes no bairro de Taboão, em junho de 1984. Rev. Inst. Adolfo Lutz, 48: 75-80, 1988.

5. DE CARLI, G.A. \& CANDIA, E.F. - Prevalência de geohelmintos entre escolares residentes nas vilas periféricas de Porto Alegre, RS. Rev. bras. Farm., 73: 7-8, 1992.

6. DE CARLI, G.A.; CANDIA, E.F. \& SARAIVA, O.J. - Epidemiologia da Giardia lamblia nas vilas periféricas da Grande Porto Alegre. Rev. bras. Farm., 71: 94-96, 1990.

7. EVANS, A.C.; HOLLMANN, A.W. \& DU PREEZ, L. - Mebendazole $500 \mathrm{mg}$ for singledose treatment of nematode infestation. S. Afr. med. J., 72: 665-667, 1987.

8. FERNANDO, S.D.; GOORETHILLEKE, H.; WEERASENA, K.H. et al. - Geo-helminth infections in a rural area of Sri Lanka. J. trop. Med. publ. Hlth., 32: 23-26, 2001.

9. FERREIRA, C.B. \& MARÇAL Jr., O. - Enteroparasitoses em escolares do distrito de Martinésia, Uberlândia, MG: um estudo-piloto. Rev. Soc. bras. Med. trop., 30: 373-377, 1997.

10. FERREIRA, M.U.; FERREIRA, C.S. \& MONTEIRO, C.A. - Tendência secular das parasitoses intestinais na infância na cidade de São Paulo (1984-1996). Rev. Saúde públ. (S. Paulo), 34(suppl. 6): 73-82, 2000.

11. GEERTS, S.; COLES, G.C. \& GRYSEELS, B. - Anthelminthic resistance in human helminths: learning from the problems with worm control in livestock. Parasit. today, 13: 149-151, 1997.

12. HEPLER, C.D. \& STRAND, L.M. - Opportunities and responsibilities in pharmaceutical care. Amer. J. Hosp. Pharm., 47: 533-543, 1990.

13. HOFFMAN, W.A.; PONS, J.A. \& JANER, J.L. - The sedimentation concentration method in schistosomiasis mansoni. Puerto Rico J. publ. Hlth., 9: 281-298, 1934.

14. JOHNSON, J.A. \& BOOTMAN, J.L. - Drug related morbidity and mortality. A cost-ofillness model. Arch. intern. Med., 155: 1949-1956, 1995.
15. JONGSUKSUNTIGUL, P.; JERADIT, C.; PORNPATTANAKUL, S. \& CHARANASRI, U. - A comparative study on the efficacy of albendazole and mebendazole in the treatment of ascarisis, hookworm infection and trichiuriasis. Southeast Asian J. trop. Med. publ. Hlth., 24: 724-729, 1993.

16. LUTZ, A. - O Schistosoma mansoni e schistosomatose, segundo observações feitas no Brasil. Mem. Inst. Oswaldo Cruz, 11: 121-155, 1919.

17. MORAES, R.G. - Contribuição para o estudo do Strongyloides stercoralis e da estrongiloidíase no Brasil. Rev. Serv. esp. Saúde públ. (Rio de J.), 1: 507-524, 1948 .

18. NONTASUT, P.; SINGHASIVANON, V.; MAIPANICH, W.; YAMPUT, S. \& VISIASSUK, K. - Comparative study of different doses of mebendazole in hookworm infection. Southeast Asian J. trop. Med. publ. Hlth., 18: 211-214, 1987.

19. NONTASUT, P.; WAIKAGUL, J.; MUENNOO, C. et al. - Minimum effective doses of mebendazole in treatment of soil-transmitted helminths. Southeast Asian J. trop. Med. publ. Hlth., 28: 326-328, 1997.

20. OLSEN, A.; SAMUELSEN, H. \& ONYANGO-OUMA, W. - A study of risk factors for intestinal helminth infections using epidemiological and anthropological approaches. J. Biosoc. Sci., 33: 569-584, 2001.

21. PRADO, M.S.; BARRETO, M.L.; STRINA, A. et al. - Prevalência e intensidade da infecção por parasitas intestinais em crianças na idade escolar na cidade de Salvador (Bahia, Brasil). Rev. Soc. bras. Med. trop., 34: 99-101, 2001.

22. SHIELD, J.; ANIAN, G.; OSTWALD, R. \& ARNHOLD, R. - Reinfection with intestinal helminths after treatment with mebendazole and fluctuations in individual Ascaris lumbricoides infections with time. Papua N. Guinea med. J., 27: 89-94, 1984.

23. SORENSEN, E.; ISMAIL, M.; AMARASINGHE, D.K. \& HETTIARACHCHI, I. - The efficacy of three anthelmintic drugs given in a single dose. Ceylon med. J., 41: 4245, 1996.

24. STEPHENSON, C.S.; CATHAM, M.C. \& OTTESEN, E.A. - Malnutrition and parasitic helminth infections. Parasitology, 121: 23-38, 2000.

25. STRAND, L.M.; MORLEY, P.C.; CIPOLLE, R.Y.; RAMSEY, R. \& LAMSAM, G.D. Drug-related problems: their structure and function. Ann. Pharmacother., 24: 1093 1097, 1990.

26. TANKHIWALE, S.R.; KUKADE, A.L.; SARMAH, H.C. \& KULKARNI, A.S. -Single dose therapy of ascariasis - a randomized comparison of mebendazole and pyrantel. J. commum. Dis., 21: 71-74, 1989.

27. TOMASO, H.; DIERICH, M.P. \& ALLERBERGER, F. - Helmintic infestation in Tyrol, Austria. Clin. Microbiol. Infect., 7: 639-641, 2001.

28 WORLD HEALTH ORGANIZATION - Report of the WHO informal consultation on the use of chemotherapy for the control of morbidity due to soil-transmitted nematodes in humans. Division of Control of Tropical Diseases. Geneva, World Health Organization, 1996.

Received: 17 December 2003

Accepted: 17 March 2004. 